in vivo $32: 983-998(2018)$

doi:10.21873/invivo.11339

Review

\title{
From Mouse Models to Human Disease: An Approach for Amyotrophic Lateral Sclerosis
}

\author{
AZIZA RASHED ALRAFIAH \\ Department of Medical Laboratory Technology, Faculty of Applied Medical Sciences and Neuroscience Research Unit, \\ King Abdulaziz University, Jeddah, Saudi Arabia
}

\begin{abstract}
Amyotrophic lateral sclerosis (ALS) is a fatal adult-onset neurodegenerative disorder. There are several genetic mutations that lead to ALS development, such as chromosome 9 hexanucleotide repeat 72 (C9ORF72), transactive response DNA-binding protein (TARDBP), superoxide dismutase 1 (SOD1) and fused in sarcoma (FUS). ALS is associated with disrupted gene homeostasis causing aberrant RNA processing or toxic pathology. Several animal models of ALS disease have been developed to understand whether TARDBP-mediated neurodegeneration results from a gain or a loss of function of the protein, however, none exactly mimic the pathophysiology and the phenotype of human ALS. Here, the pathophysiology of specific ALSlinked gene mutations is discussed. Furthermore, some of the generated mouse models, as well as the similarities and differences between these models, are comprehensively reviewed. Further refinement of mouse models will likely aid the development of a better form of model that mimics human ALS. However, disrupted gene homeostasis that causes mutation can result in an ALS-like syndrome, increasing concerns about whether neurodegeneration and other effects in these models are due to the mutation or to gene overexpression. Research on the pleiotropic role of different proteins present in motor neurons is also summarized. The development of better mouse models that closely mimic human ALS will help identify potential therapeutic targets for this disease.
\end{abstract}

This article is freely accessible online.

Correspondence to: Aziza Alrafiah, P.O Box 80200, Jeddah 21589, Saudi Arabia. Tel: +966 0126401000 Ext. 23495, Fax: +966 0126401000 Ext. 21686, e-mail: aalrafiah@kau.edu.sa

Key Words: Amyotrophic lateral sclerosis, motor neuron diseases, mouse models, C9ORF72, FUS, SOD1, TARDBP, review.
Amyotrophic lateral sclerosis is a devastating adult neurodegenerative disorder characterized by motor neuron degeneration and death approximately 3 years after onset. Riluzole is currently the only treatment available, but only offers a slight survival benefit (1). The etiology of ALS is complex and is associated with several genes, making it difficult to study the etiopathogenesis of this disease (2) (Figure 1).

During the past decade, significant advances have been made in understanding this disease, from linkage analysis to isolation of defective genes and identification of their protein product (3). The development of animal models for the study of this disease, in particular, mouse models for ALS (1), has now made it possible to understand the molecular basis of this disease and has demonstrated the feasibility of using the whole affected gene, which is found in all patients with ALS, as a means of treating this disorder.

The most common form of ALS is sporadic ALS, which is an age-associated disease characterized by cytoskeletal abnormalities and the death of motor neurons (4). The familial form of ALS (FALS) is an inherited autosomal dominant disease linked to mutations in superoxide dismutase 1 (SOD1) gene, which manifest as inclusions and degeneration of motor neurons. It has been reported that $5-10 \%$ of all patients with ALS have the inherited form of $\operatorname{ALS}(5,6)$.

A non-coding hexanucleotide C9ORF72 gene repeat expansion is the most common mutation associated with frontotemporal dementia (FTD) and FALS (7). Transgenic ALS mouse models that express SOD1 have been critical in furthering our understanding of the disease (8). Transactive response DNA-binding protein 43 (TDP43) ubiquitinated inclusions are a hallmark of ALS and FTD with ubiquitinpositive inclusions. However, mutations in the gene encoding these inclusions $(T A R D B P)$ are associated with only $3 \%$ of sporadic and FALS $(8,9)$. Moreover, mutations in the gene encoding the RNA-binding protein fused in sarcoma (FUS) can cause FALS but rarely FTD (10). 
Experimental models of ALS are important for clarifying the complex functions of different proteins and the pathology of ALS (11). In order to examine the mechanisms underlying ALS, investigators have used a variety of animal models, including experimentally produced, spontaneously occurring, or genetically-engineered disease models. While these models have provided important insight into the underlying mechanisms of ALS, they are not without their limitations in that they allow study of different aspects of the disease.

This review discusses the major neuropathological features and mechanisms of ALS-associated mutations, as well as behavioral/neuropathophysiological features of recently developed mouse models, and the results of their biochemical mechanisms with the aim of potentially using these models to test new therapies for ALS.

\section{The C9ORF72 Mutation}

Since its discovery in November 2011, the C9ORF72 mutation has been reported as the most frequent mutation associated with ALS and FTD in Western countries $(12,13)$. The C9ORF72 gene has a high penetrance, and most persons with the C9 expansion die due to a neurodegenerative disorder. Although some patients who carry this mutation develop a range of FTD disorders, others exhibit ALS symptoms; some patients have a mixture of both FTD and ALS at presentation (14). A number of important questions regarding this mutation remain unanswered, especially those pertaining to selective vulnerability and why ALS develops in one member of a family whereas another family member dies from FTD

The discovery of $C 9 O R F 72$ repeat expansions has helped scientists understand the mechanism underlying neurodegeneration in ALS, which appears to be related to dysfunctional RNA processing (15). The repeat has been identified on a non-coding region of C9ORF72, which encodes a protein with no identified function that is expressed at high concentrations in the brain $(15,16)$. RNA aggregates are formed within the nucleus due to the very long hexanucleotide repeat, which is thought to range between 700 and 1,600 units (16). It is also thought that the long hexanucleotide repeat suppresses gene expression through abnormal RNA splicing. Another hypothesis that has been proposed to explain the mechanism of the disease is C9ORF72 protein function loss (17). It will be challenging to develop therapies for $C 9 O R F 72$ and this might necessitate the development of new therapeutic strategies that involve suppressing the expression of the C9 repeat (17). The development of robust animal models and use of welldefined patient cohorts are crucial to understanding how the disease develops and help in discovering potential therapeutic targets $(17,18)$.
Mouse models. Besides inclusion formation, evidence suggests that patients with G4C2 repeat expansion have increased repressive histone hypermethylation at the C9ORF72 repeat expansion locus (16). Scientists developed C9ORF72 knockout cell and mouse models to understand the underlying mechanism in C9ORF72-associated ALS/FTD pathogenesis.

A decrease in C9ORF72 transcript expression in animal models has been associated with neurodegenerative and behavioral deficits $(17,18)$.

Experiments on animal models have shown that a decrease in C9ORF72 led to decrease in RNA foci and dipeptide repeat proteins (DPR), contrary to findings in patients with C9ORF72-associated ALS/FTD $(19,20)$. Nevertheless, in other models that do not support the loss of function (LOF) argument, the administration of antisense oligonucleotides against C9ORF72 transcript did not cause adult mice to develop behavioral or neurodegenerative disorder (20). On the contrary, it reduced symptomatology (21). Moreover, patients with C9ORF72-associated ALS/FTD did not show a mutation in the coding region of the gene. Inclusions were, however, documented (22). Consequently, while abnormal C9ORF72 repeat expansions may be implicated in the etiopathogenesis of ALS, there is no strong clinicopathological evidence that LOF leads to neurodegeneration in C9ORF72-associated ALS/FTD.

Given the difficulty in cloning GGGGCC (G4C2) expansions and the instability of these expansions in somatic cells, investigators face challenges in developing transgenic mouse models (23). However, much research has been ongoing in this area to assess the pathological functions of G4C2 expansion on in vitro and in vivo model systems. It was not until recently that scientists were able to develop transgenic mouse models that recapitulate the pathology and symptoms of human ALS/FTD (22).

Some investigators $(23,24)$ used bacterial artificial chromosome (BAC) to develop the first transgenic mice. These mice carried the G4C2 expansion and expressed approximately 500 and 1,000 repeats of the human C9 gene at moderate levels, respectively $(23,24)$. Although models exhibited histological phenotypes similar to human C9ORF72-associated ALS/FTD, the mice had normal phenotypes. Histological investigations demonstrated the production and deposition of RNA foci and poly-(glycineproline) peptides in the brain and spinal cord (25). Other researchers used a virus-mediated gene-delivery system to develop transgenic mice harboring 66 repeats of $\mathrm{G} 4 \mathrm{C} 2$ motifs or dipeptide repeat (DPR) proteins $(26,27)$. The mice expressed high levels of synthetic C9-RNA and DPR, and showed histopathological features and phenotypical neurodegenerative defects comparable to those observed in patients with ALS and FTD $(26,27)$. Of note, transgenic mice overexpressed synthetic peptides at levels exceeding the 


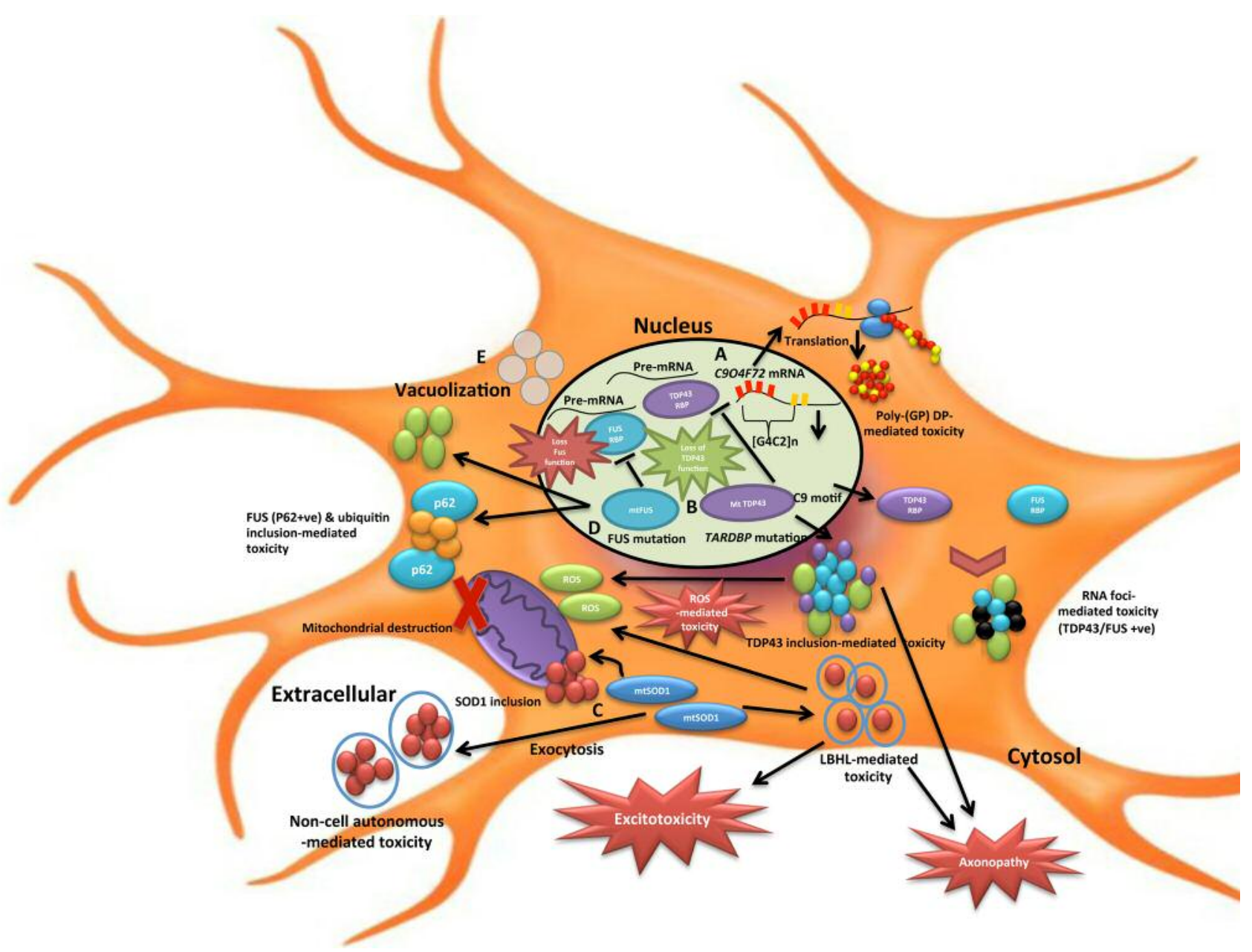

Figure 1. Pathogenesis of C9OR72-, TARDBP-, SOD1-, and FUS-associated amyotrophic lateral sclerosis (ALS). A: Chromosome 9 hexanucleotide repeat72 (C9ORF72) 2 mutation acts through a gain-of-function (GOF) mechanism. GGGGCC[G4C2] is translocated to the cytosol and then either translated to form aggregates of poly-(GP) dipeptide-repeat proteins $(D P R)$ or misfolded to form aggregates of ubiquitinated (U) RNA foci associated with TDP43 or FUS proteins, which both mediate neuronal toxicity. B: transactive response DNA-binding protein (TARDBP) mutation acts through both loss of function (LOF) and GOF mechanisms. Normal TDP43 function is lost due to mutant (mt) TDP43 proteins inhibiting normal TDP43 from binding to pre-mRNA. C: superoxide dismutase 1 (SOD1) mutation acts through a GOF mechanism. Mutant SOD1 dimers in the cytosol accumulate as SOD1 inclusions within mitochondria and Lewy-body-like hyaline (LBLH) inclusions in the cytosol where they can trigger mitochondrial reactive oxygen species (ROS) generation later, causing mitochondrial destruction. D: fused in sarcoma (FUS) mutation acts through both LOF and GOF mechanisms. Mutant FUS proteins cause LOF by inhibiting normal FUS from binding to pre-mRNA. E: Cytosol vacuolization is caused by all the above-mentioned mutations.

normal physiological levels noted in patients. Conversely, other investigators used BAC transgenic mice and successfully reproduced the histopathological, molecular and clinical features of the disease $(28,29)$. In the latter two studies, the investigators found that the number of RNA foci, DPR aggregates and neuronal loss were proportional to repeat length. Nevertheless Liu et al., found that only symptomatic mice with acute end-stage disease presented cytoplasmic and nuclear TDP43 inclusions in the entirety of the denervated brain, hippocampus, and motor cortex $(28,29)$. The other group contended that mice expressing up to $450 \mathrm{C} 9 \mathrm{ORF} 72$ RNAs ( $C 9^{450}$ mice) did not display TDP43 mislocalization or aggregation, although higher levels of phosphorylated TDP43 were observed (28). Liu et al. reported a dramatic decrease in survival among mice from the C9-500/32 (two transgene copies, one with $\sim 500$ and the other with 32 repeats) and C9-500 (one copy with $\sim 500$ repeats), lines compared to non-transgenic controls $(28,29)$. Although the results of Jiang et al.'s study provide deep insight into critical drivers of disease pathogenesis and an understanding of the 
molecular mechanisms of ALS and FTD (28), further research is warranted to elucidate the molecular basis of sexspecific differences. In addition, the data do not explain differences observed between the four C9ORF72 BAC lines that were selected for analyses $(28,29)$. Put together, there is no solid basis to assume that the full-length gene construct is not obligatory for neurodegeneration since investigators used different constructs and observed dissimilar results. Jiang et al. (28), and Liu et al. (28, 29) for example, reported neurodegenerative disorders despite using part of the gene in their construct, whereas Rourke et al. did not observe behavioral abnormalities or neurodegeneration even at advanced ages (23).

The discrepancies in disease manifestation between the developed mouse models prompted the identification of models that closely mimic human ALS (Table I). A set of criteria were used to select these mouse models, including late-onset ALS, low expression of a misfolded protein, occurrence of gliosis or paralysis, and presence of cytosolic inclusions at presentation.

In most cases, C9ORF72 models support the toxic gain of function (GOF) mechanism, which is evidenced by the accumulation of abnormal protein aggregates. On the other hand, no significant replication of ALS has been reported in knockdown models. Currently, research acknowledges the potential of the use of antisense oligonucleotides as a therapeutic approach for $C 9 O R F 72$-related disease since they can target genes such as SOD1 and C9ORF72, and alleviate toxicity due to $\mathrm{G} 4 \mathrm{C} 2$ repeat while maintaining the normal function of C9ORF72 (23).

\section{The SOD1 Mutation}

In 1994, a breakthrough was achieved with the discovery of genetic mutations in the SODI gene that were linked to FALS (30). SOD1 mutations remained the only known cause of 'classical' ALS until causative mutations in the TARDBP gene were found $(30,31)$. During the subsequent two decades, more than 180 SODI mutations have been identified, with most being missense point mutations, mainly substitution. However, insertion and deletion point mutations have also been identified (32).

Recent research on ALS genetics support the role of proteins in RNA metabolism and cytoskeletal organization, typically in the central nervous system (33). On the contrary, SOD1 is expressed in several tissues, and is not limited to the spinal cord and motor neurons $(34,35)$. In addition, the level of SOD1 in tissues is not developmentally regulated (36). The SOD1 enzyme has a well-defined catalytic function, whereby it detoxifies the superoxide species in cells (36). Scientists quickly ruled-out deficient SOD1 enzymatic activity in their quest to identify the possible underlying mechanism for ALS since mutations preserving or abolishing SOD1 activity were found to cause ALS disease (37). These factors by themselves suggest that there is no outright explanation for the involvement of SOD1 in adult-onset neurodegenerative disease.

Here focus is placed on a few of the varied yet organized motor neuron toxicity due to the formation of aggregates caused by the instability of the SOD1 protein (36). Among these are excitotoxicity, deficient axonal transport, and mitochondrial dysfunction (36). Like in all ALS-associated mutations, there is cytoplasmic accumulation of misfolded SOD1 in the form of inclusions, namely Lewy-body-like hyaline inclusions (LBHI), which are the most frequent inclusions in SOD1 mutants. These inclusions are located on mitochondrial neurons and astrocytes, and as a result, these suffer morphological damage $(38,39)$. LBHI is made up of several components, including mutated and wild-type SOD1, granule-coated fibrils, as well as ubiquitin (40). A disruption of $\mathrm{Ca}^{2+}$ intracellular reservoirs results from mitochondrial dysfunction, and, consequently, excess $\mathrm{Ca}^{2+}$ is stored in the mitochondria. This results in motor neurons becoming very sensitive to glutamate (excitatory neurotransmitter), causing excitotoxicity $(39,41)$. In TDP43 pathogenesis, it has been suggested that axonal transport disruption is attributed to damaged axonal cytoskeleton (42).

A growing body of evidence suggests that dysfunctional axonal transport plays a role in the pathogenesis of ALS (43). Defects in both anterograde and retrograde axonal transport have been described in Sod1 $1^{G 93 A}$ transgenic mice (43). Previous research has demonstrated that one of the first axonal pathologies in $S o d 1^{G 93 A}$ transgenic mice was the block of axonal retrograde transport (43). This suggests that ineffective axonal transport is a major pathogenic driver of ALS. Furthermore, some investigators demonstrated impairment of both fast and slow axonal transport in transgenic mice that exhibited low levels of mutant SOD1 (44). Severe defects in axonal transport have been observed in mice overexpressing human neurofilament heavy-subunit gene (45). Patients with sporadic ALS or FALS present point mutations of the $\mathrm{p} 150$ subunit of dynactin (46), which can cause a decrease in retrograde transport; however, the disease progresses at a slower rate than ALS in transgenic mice (47). Conversely, mutations in cytoplasmic dynein can cause pure sensory neuropathy or a sensory neuropathy with motor neuron involvement (48). It is thought that the progression of SOD1associated ALS is caused by non-cell autonomous toxicity. Misfolded mutant SOD1 is secreted in association with components of neurosecretory vesicles by motor neurons or glial cells (49). The secreted mutant SOD1 will, in turn, affect other motor neurons and glial cells, especially astrocytes and microglia (50), causing the development of motor neuronal damage and, consequently, disease progression.

Contrary to health astrocytes, which have the capacity to block $\mathrm{Ca}^{2+}$ from entering motor neurons, mutant astrocytes 
Table I. Mouse models for chromosome 9 hexanucleotide repeat 72 (C9ORF72)-related amyotrophic lateral sclerosis.

\begin{tabular}{|c|c|c|c|c|c|c|}
\hline \multirow[b]{2}{*}{ Clinicopathological feature } & \multicolumn{6}{|c|}{ C9ORF72 Mutation (Ref) } \\
\hline & (23) & (24) & (26) & (27) & $(28)$ & (29) \\
\hline No. of $\mathrm{C} 9$ repeats & $100-1,000$ & 500 & NA & 66 & 450 & 500 \\
\hline Promoter & $\mathrm{BAC}^{1}$ & $\mathrm{BAC}^{1}$ & $\mathrm{NA}^{2}$ & $\mathrm{NA}^{2}$ & $\mathrm{BAC}^{1}$ & $\mathrm{BAC}^{1}$ \\
\hline Age of disease onset (months) & ND & ND & 6 & 6 & 13 & 4 \\
\hline Cognitive deficit & No & No & Yes & Yes & Yes & Yes \\
\hline Cortical MNL & No & No & Yes & Yes & No & Yes \\
\hline Hippocampal MNL & No & No & Yes & No & Yes & Yes \\
\hline Cerebral MNL & No & No & Yes & Yes & ND & Yes \\
\hline Spinal cord MNL & No & No & No & No & No & Yes \\
\hline Gliosis & No & No & No & Yes & No & Yes \\
\hline Paralysis & No & No & No & No & No & Yes \\
\hline Mechanism & ND & ND & GOF & GOF & GOF & GOF \\
\hline Cytoplasmic inclusion & $\begin{array}{l}\text { DPR (poly-GP), } \\
\text { RNA foci }\end{array}$ & $\begin{array}{l}\text { DPR (poly-GP), } \\
\text { RNA foci }\end{array}$ & $\begin{array}{c}\text { DPR, sparse } \\
\text { phospho- } \\
\text { TDP43 }\end{array}$ & $\begin{array}{l}\text { DPR (poly-GP), } \\
\text { RNA foci, } \\
\text { phospho-TDP43 }\end{array}$ & $\begin{array}{c}\text { DPR } \\
\text { and } \\
\text { RNA foci }\end{array}$ & $\begin{array}{c}\text { DPR, RNA foci, } \\
\text { TDP43e, } \\
\text { vacuolization }\end{array}$ \\
\hline Age of death (months) & ND & ND & ND & Unknown & ND & $5-10$ \\
\hline
\end{tabular}

GOF: Gain of function; MNL: motor neuron loss; NA: not applicable; (ND): not described; DPR: dipeptide-repeat proteins; BAC: bacterial artificial chromosome. ${ }^{1}$ This includes the promoter sequence of a human gene. ${ }^{2}$ Viral delivery.

lack the ability to regulate the GluR2 subunit, rendering motor neurons vulnerable to excitotoxicity $(23,51,52)$. A site-specific recombinase technology (Cre-Lox system) has been used to remove SOD1 mutants from astrocytes and microglia (51-53). This system slowed disease progression but did not prevent disease onset, although it has been demonstrated that the removal of mutant SOD1 expression from neurons prevented disease onset (53). Thus, it is possible that astrocyte cell replacement therapy can improve survival in patients with ALS (53). Mutant SOD1 causes other forms of neuronal damage, including endoplasmic reticulum stress, proteasome inhibition, and synaptic vesicle defects (54), which will not be covered in this review.

Mouse models. Many transgenic mouse models have been developed since the discovery of mutant SOD1-induced ALS. These models have helped scientists to understand the mechanism underlying ALS. It has now been established that SOD1 gain and LOF can complement each other in the pathogenesis of AMS (55). In some models, Sod1 ${ }^{-/}$ knockout mice did not develop the ALS phenotype. Rather, these mice had signs of decreased fertility, axonal repair difficulties, higher oxidative stress, weakness, and in severe cases, early post-natal mortality without expressing any phenotypes of ALS up to 6 months of age (56-58).

Conversely, overexpression of human wild-type SOD1 did not result in the development of symptoms typical of ALS. Thus, some mice showed late deficient hindlimb splaying at 8 months of age, whereas mutant SODl transgenic mice exhibited the ALS phenotype at an earlier age $(30,35)$. Most models in the literature were created by the administration of a 12-kb fragment of human genomic DNA that contains all regulatory elements as the transgene vector (59). Researchers have introduced the following mutant SOD1 genes into mice: A4V, G93A, G37R, D90A, and G85R. Mice with these gene variants had phenotypes that mimicked several features of ALS (Table II).

Furthermore, these phenotypes depend on the patient's genetic profile, gender, mutation type, and accumulation of mutant SOD1 protein. It was demonstrated that contrary to mice, patients with the $\mathrm{A} 4 \mathrm{~V}$ mutation had rapid disease progression and death within 1 year of symptom manifestation (60). Conversely, investigators noted that the disease was slowly progressive in both mice and humans who had D90A mutation (60). Furthermore, slow disease progression and prolonged survival were common among female mice (61). Similar observations were noted in humans (62). The mouse models most widely used by ALS researchers are those expressing approximately 25 copies of the transgene $\operatorname{Sod1} 1^{G 93 A}$ under the influence of a human SOD1 promoter (3). These are ideal for studying the pathogenesis of ALS because they closely mimic the disease in patients with SOD1-related ALS. LBHI accumulation, neuronal loss in the ventral horns of the spinal cord, and reactive gliosis have been described in patients with SOD1related ALS (62). Nevertheless, some features such as CNS vacuolization have only been observed in mutant Sodl mice and infrequently in humans (62). It is thought that these are due to the accumulation of remnants of damaged mitochondria. Sod1 ${ }^{G 93 A}$ mice can live for approximately 


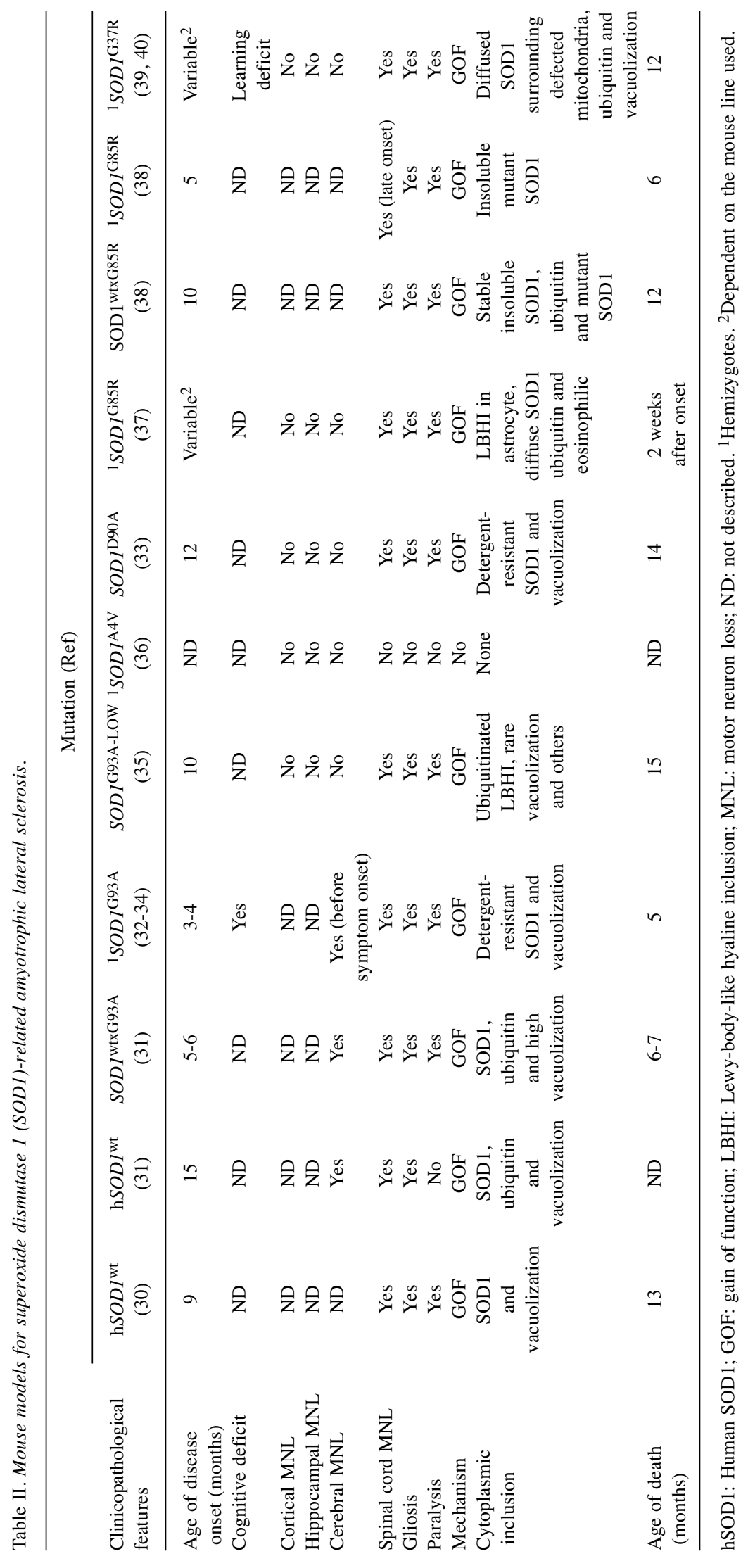


Table III. Mouse models for fused in sarcoma (FUS)-related amyotrophic lateral sclerosis.

\begin{tabular}{|c|c|c|c|c|c|c|c|}
\hline \multirow[t]{2}{*}{ Clinicopathological features } & \multicolumn{7}{|c|}{ Mutation (Ref) } \\
\hline & $\begin{array}{c}\mathrm{h} F U S^{\mathrm{wt}} \\
(71,75,85)\end{array}$ & $\begin{array}{c}\mathrm{h} F U S^{\mathrm{wt}} \\
(71,75,85)\end{array}$ & $\begin{array}{c}{ }^{1} \mathrm{~h} F U S^{\mathrm{wt}} \\
(71,75,86)\end{array}$ & $\begin{array}{c}{ }^{2} F U S^{\mathrm{R} 52 \mathrm{IC}} \\
(72,73,82)\end{array}$ & $\begin{array}{c}{ }^{1} F U S^{\mathrm{R} 521 \mathrm{C}} \\
(72,73,82)\end{array}$ & $\begin{array}{c}{ }^{2} F U S^{\mathrm{P} 525 \mathrm{~L}} \\
(71)\end{array}$ & $\begin{array}{c}{ }^{1} F U S^{\mathrm{R} 521 \mathrm{G}} \\
(72,73,82)\end{array}$ \\
\hline Promoter & $\mathrm{mPrp}$ & tau & CAG & tau & hamPrp & tau & CAG \\
\hline Age of disease onset (months) & 1.0 & ND & Approximately 0.1 & 2.0 & 1.0 & 1.0 & Approximately 0.5 \\
\hline Cognitive deficit & NA & ND & NA & ND & ND & ND & $\begin{array}{l}\mathrm{Y} \text { (only mice } \\
\text { that survived) }\end{array}$ \\
\hline Cortical MNL & No & No & No & ND & Yes & ND & No \\
\hline Hippocampal MNL & No & ND & ND & ND & ND & ND & ND \\
\hline Spinal cord MNL & Yes & No & No & Yes & Yes & Yes & No \\
\hline Gliosis & Yes & No & Yes & Yes & Yes & Yes & Yes \\
\hline Paralysis & Yes & No & Yes & Yes & Yes & Yes & Yes \\
\hline Mechanism & GOF & ND & LOF & GOF & LOF & GOF & GOF and LOF \\
\hline Cytoplasmic inclusion & $\begin{array}{c}\text { Diffused and } \\
\text { intense FUS, } \\
\text { perinuclear } \\
\text { inclusions and } \\
\text { ubiquitin }\end{array}$ & None & None & $\begin{array}{c}\text { Diffused } \\
\text { FUS }\end{array}$ & $\begin{array}{c}\text { Low } \\
\text { FUS } \\
\text { aggregates }\end{array}$ & $\begin{array}{l}\text { Highly } \\
\text { diffused } \\
\text { FUS }\end{array}$ & None \\
\hline Age of death (months) & 3 & ND & $<1$ & 12 & $2-2.5$ & 12 & $<1(70 \%$ of mice $)$ \\
\hline
\end{tabular}

hFUS: Human FUS; GOF: gain of function; LOF: loss of function; MNL: motor neuron loss; NA: not applicable; ND; not described. ${ }^{1}$ Hemizygotes. ${ }^{2}$ Heterozygotes.

4 months after developing signs of motor neuron degeneration and paralysis. In previous reports, investigators have observed other signs such as muscle denervation at the neuromuscular junction (NMJ), microgliosis, and extensive inflammation of the brain $(55,57)$. Of note, motor neuron degeneration did not improve after eliminating microglia expressing mutant $\operatorname{Sod} 1^{G 93 A}$, whereas a decrease of mutant Sod1 $1^{G 37}$ in astrocytes led to a significant prolongation of survival in transgenic mice $(52,63)$. Although significant progress has been made in identifying the mechanism underlying motor neuron degeneration in SOD1-related ALS, further study is warranted to understand disease progression among the different variants (64).

\section{The FUS Mutation}

The FUS mutation is the second most frequent mutation associated with ALS (64-66), accounting for 5\% of cases in patients with FALS (64). Mutations in the FUS protein have been identified in patients with FALS, sporadic ALS, FTD, and frontotemporal lobar degeneration without motor impairment $(64,67)$. Clinically, the disease is aggressive and has been associated with young age $(68,69)$.

In most cases, mutations have been identified clustered in the $C$-terminal portion of the FUS protein, which consists of several domains, including the RNA-recognition motif, $C$-terminus, and nuclear localization signal (NLS) $(70,71)$. Researchers identified a new mutation that triggers juvenile FUS-associated ALS, located in the $C$-terminal amino acid
(Y526C) (72). FUS proteins play a role in controlling transcription, processing RNA, and repairing DNA (73) FUS proteins can translocate intracellularly between the nucleus and the cytoplasm similar to TDP43 (74).

In patients with FUS mutation, an impairment of DNArepair pathways and RNA splicing can cause physiological defects such as dendritic growth retardation, NMJ denervation, and neuron dysfunction (75). However, it is believed that the impairment of DNA-repair mechanisms is not due to the binding of mutant FUS to the DNA foci but rather due to the interaction with histone deacetylase 1 (76-78) Juvenile ALS with basophilic inclusions is pathologically and genetically different from the classic form of sporadic ALS. Basophilic inclusions are positive for FUS protein; however, these are negative for TDP43 (78). Moreover, the intensity of basophilic inclusions, especially in the horn of the spinal cord and cortical neurons, is a reflection of disease severity (79).

The administration of rosiglitazone in FUS transgenic rats prevented neuronal loss by inhibiting the development of abnormal dendrites, thus preserving their spatial memory (80). This suggests that neuronal loss is downstream of dendritic disruption, and this might also be the case in NMJ denervation. The use of FUS transgenic rats can potentially help understand the mechanism underlying cortical dementia in frontotemporal lobar degeneration (80).

Mouse models. A mutation in the FUS gene can cause ALS by both LOF and toxic GOF, contrary to other forms of ALS (Table III). 


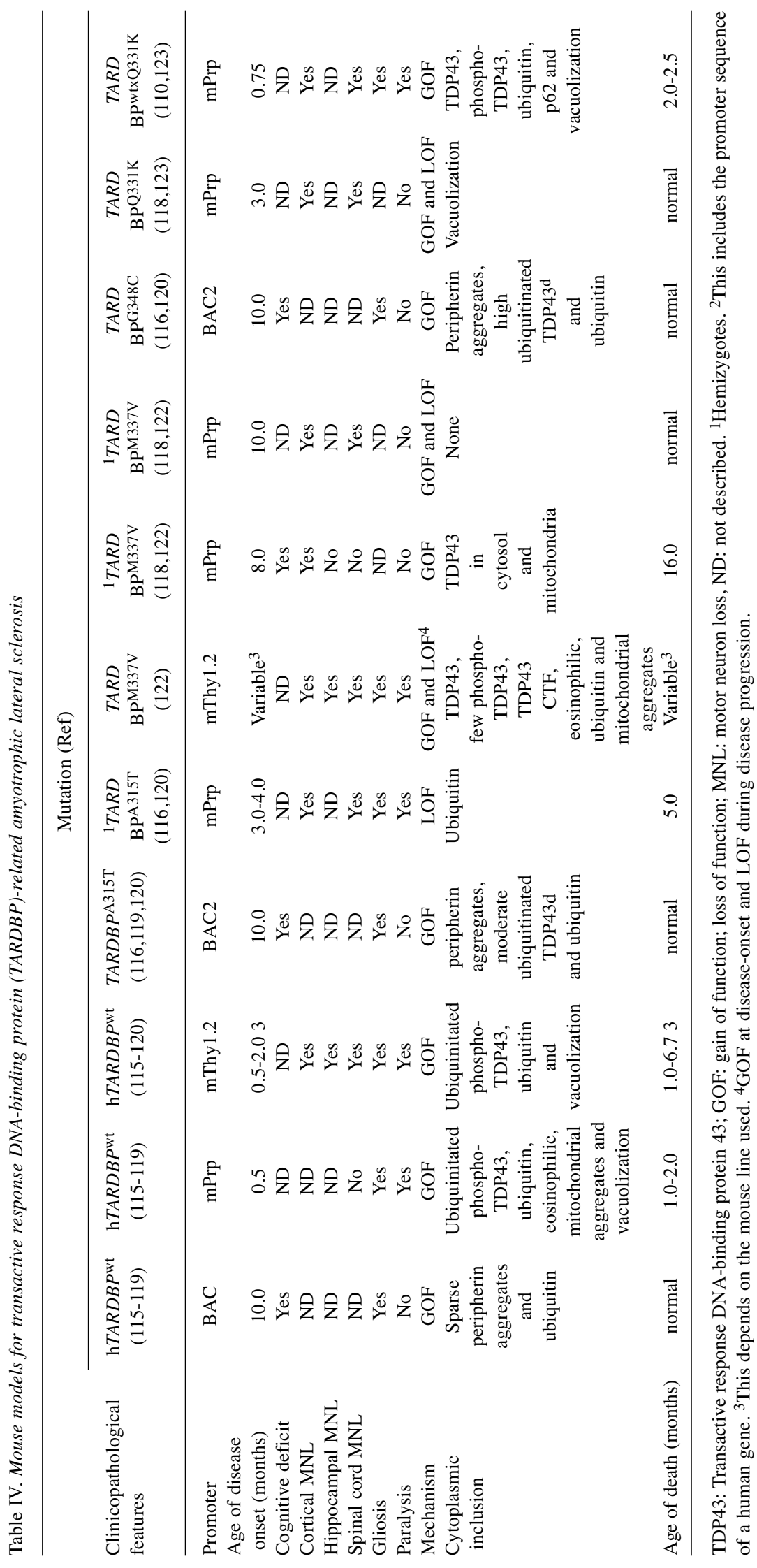


In one report, antisense morpholino oligonucleotide was used to knock-down fus gene in zebrafish (81). Neurological disorders such as NMJ denervation associated with abnormal synaptic activity and motor neuronal excitotoxicity were observed in this model (81). Of note, the investigators also observed symptoms that mimicked ALS in another group of zebrafish overexpressing mutant FUS (17). These observations demonstrate that LOF is the key pathogenic mechanism in FUS-related ALS. Nevertheless, there was no evidence to exclude toxicity due to GOF. In a more recent study, investigators developed a transgenic mouse model expressing FUS ${ }^{R 521 C}$ mutation driven by the Syrian hamster prion promoter (82). While significant and progressive neuronal loss were observed in these mice, no cytoplasmic inclusions were noted. Conversely, in most cases, endogenous FUS was not able to function properly (83). Overall, by identifying defects in transcription and RNA splicing in knockdown mouse models, investigators have demonstrated that LOF should be considered as a mechanism of action in FUS-induced ALS (83). Nevertheless, additional research is warranted, as controversy continues to surround this hypothesis.

Other researchers hold that toxic GOF is involved in the development of FUS-related ALS (84). It was shown that homozygous mice overexpressing human wild-type FUS under the mouse prion promoter had progressive and lethal neurodegenerative disease despite having FUS protein levels only 1.7-fold higher than non-transgenic mice (85). Mice with FUS mutation developed tremors at 1 month of age and showed signs of spinal cord neuronal loss and gliosis (86). Nevertheless, researchers did not identify physiological alterations in the brain (87). Furthermore, the accumulation of FUS inclusions was observed in the cytoplasm of the anterior horn of the spinal cord and brain, but did not co-localize with ubiquitin inclusions (88). Of note, wild-type FUS is characteristic of FTD and not ALS, although the mice displayed signs typical of ALS (71). These observations support the hypothesis that the disease acts through a GOF mechanism due to cytoplasmic accumulation of FUS and the absence of inclusions in the nucleus (81). Other investigators did not observe significant motor neuron loss or NMJ denervation in wild-type transgenic mice (75). In their model, the mice expressed a single copy of human wild-type FUS using Cre-LoxP recombinant at the microtubule-associated protein tau (MAPT) locus (75). The investigators utilized the same promoter to develop transgenic mice overexpressing human mutant $F U S^{R 521 C}$ and $F U S^{P 525 L}$, which have been reported to cause late-and early-onset disease in humans, respectively (71). Contrary to the healthy wild-type model, $F U S^{R 521 C}$ and $F U S^{P 525 L}$ mice exhibited denervated NMJ and progressive neurodegeneration at 2 and 1 month of age, respectively (71). This indicates that the FUS $S^{P 525 L}$ mutation causes more aggressive disease than the FUS ${ }^{R 21 C}$ mutation. In one report, the investigators found that mutant FUS, besides being more pathogenic, was more stable than human wild-type
FUS (72). In both mutant models, diffused condensed inclusions of human wild-type FUS were observed. In addition, researchers documented an abnormal accumulation of FUS in the cytosol rather than in the nucleus $(72,73,82)$. FUS $S^{P 25 L}$ mice demonstrated more cytoplasmic FUS than $F U S^{R 521 C}$, indicating that the frequency of FUS accumulation is directly related to the severity of ALS (82). Furthermore, to support their argument that the disease acts through a GOF toxicity mechanism in these models, the investigators developed a conditional FUS knockout model to overcome the prenatal lethality of consecutive FUS knockouts (75). The investigators concluded that the toxicity observed in FUSrelated ALS does not involve an excess of human FUS or require the interaction of the mutant gene and wild-type forms. Rather, it is thought that toxicity is only due to accumulation of mutant FUS $(17,73,75)$.

Lastly, there is evidence that the disease acts through a GOF or LOF mechanism depending on the type of mutation (89). Investigators developed human wild-type FUS or FUS ${ }^{R 521 G}$ mice models by utilizing a Cre-inducible transgenic approach. Mortality rates were approximately $70 \%$ and $100 \%$ in mice expressing $F U S^{R 521 G}$ and human wild-type FUS, respectively $(82,85)$. In both groups, mortality was due to loss of motor function, which occurred before the mice were 1 month old. $F U S^{R 521 G}$ tat mice (Tat transgenic mice that express Tat protein; a number of studies have documented its neurotoxic property and its association with neurological diseases) survived and exhibited impaired motor function and mild behavioral disorders compared to their littermates $(82,85)$. Most mice expressing human wild-type FUS and $F U S^{R 521 G}$ developed hindlimb clasping, NMJ denervation, and muscle atrophy prior to motor loss $(82,85)$. This finding contradicts those of previous researches that demonstrated that wild-type FUS was less severe than mutant FUS. Similarly to the model generated by Qiu et al. (82), cytoplasmic FUS proteins were not detected in these models. Nevertheless, both mutants were distinct in terms of their gene-expression profile and synaptic homeostasis. Mice that expressed human wild-type FUS exhibited low gene expression, implying that endogenous FUS was non-functional. Thus, the expression of human wild-type FUS was through the LOF mechanism. Mice that expressed $F U S^{R 521 G}$, contrary to transgenic mice that expressed human wild-type FUS, showed disrupted branching of dendrites, which was thought to be caused by toxic GOF. Nevertheless, it is worth mentioning that $F U S^{R 521 G}$ mice also demonstrated low gene expression, a finding that is in line with that reported by Qiu et al. (82). This supports the hypothesis that FUSrelated ALS acts through a partial LOF and GOF.

\section{The TARDBP Mutation}

TDP43 has been identified as the main component of cytoplasmic and intracellular inclusions in neurons and glia 
of patients with sporadic and FALS (90). Over 30 distinct mutations in the gene encoding TDP43, TARDBP, have been identified, and 3-4\% occurred in patients with FALS (91, 92). While FUS and TDP43 proteins share similar structures and functions, suggesting that they probably have the same disease mechanisms, their functions of both proteins, for the most part, uncharacterized.

More than 50 missense mutations in the TARDBP gene have been identified, and these are related to polymorphism or substitution. Mutations in the TARDBP gene cause TDP43 hyper-phosphorylation and ubiquitin aggregation (93). Of note, TDP43 inclusions are found in most patients with ALS and ALS-associated FTD, except for those who have mutations associated with SOD1. For example, TDP43 inclusions have been described in progranulin $(G R N)$ gene, valosin-containing protein $(V C P)$, and $C 9 O R F 72$ mutations (94). The presence of TDP43 inclusions can lead to a variety of proteinopathies, including axonopathy, mitochondrial degeneration, and abnormal RNA regulation (95). Under normal circumstances, TDP43 proteins help transport target mRNAs from the soma to distal axonal compartments as well as the NMJ (95). A deficiency of TDP43 causes retrograde movement of mRNA granules in Drosophila motor neurons and mouse cortical neurons (65).

Oxidative stress accumulation is also common in neurodegenerative diseases caused by protein mutation. Glutathione depletion triggers the formation of TDP43 inclusions (96), suggesting a relationship between reactive oxygen species and TDP43 impairment. Other investigators further demonstrated that TDP43 aggregates trigger oxidative stress and cause the formation of stress granules that recruit more TDP43, leading to the formation of large protein inclusions (97). These, then ubiquitinate mRNA molecules, including HDAC6 and fission factors, causing the degradation of mitochondria and subsequently, neurodegeneration $(98,99)$. Nevertheless, mitochondrial aggregation following the attachment of TDP43 did not require fission protein (100). Rather, this involved dysfunction of tau protein, which facilitates axonal transport of neurotransmitters (101). While these findings point towards a possible role of TDP43 inclusions in proteinopathies, researchers still have to determine whether these inclusions can cause neurodegeneration or are just a downstream consequence.

Mouse models. TDP43 affects many biological processes, including embryogenesis and neuronal development (102, 103). Cell dysfunction results if TDP43 does not function properly (104). That said, it was challenging for researchers to develop mouse models to study a single disease.

While some researchers successfully generated TDP43 models (105), the experiments had shortcomings in the sense that none could recapitulate the classical TDP43-associated
ALS-like phenotype. To understand whether TARDBPrelated ALS acts through LOF, researchers generated knockout mouse models. They found that embryogenesis was impaired in homozygous knockout mice, suggesting that TDP43 played a part in disease pathogenesis (106). Conversely, there was evidence that TDP43 synthesis was autoregulated, as heterozygous knockout mice did not have symptoms of neuromuscular disease and had normal protein expression (106-108). Symptoms typical of ALS were not exhibited in any of the generated knockout models. Overall, it can be deduced that TDP43 aggregation is likely the main cause of ALS/FTLD through a GOF rather than LOF (109).

Furthermore, in order to study the nature of GOF toxicity in ALS and the nature of GOF toxicity in ALS in which high levels of TARDBP mRNA and protein in defected neurons have been reported, researchers generated transgenic mice overexpressing human wild-type TDP43 carried by exogenous promoters such as Cre, Thy 1.2, Prp and Camkll $\alpha$ $(108,110)$. The mice in this model exhibited phenotypes similar to those observed in Camkll $\alpha$ mice. These include the presence of fragmented and phosphorylated TDP43 inclusions in the cytosol, early neuronal loss, gliosis, axonopathy, intestinal dysfunction, progressive paralysis, and death. However, these signs are not pathognomonic for ALS and may be observed in different types of TDP43 proteinopathies $(66,111,112)$. These findings raise concerns regarding the reliability of these mouse models in the study of ALS pathogenesis.

Researchers have also attempted to understand the role of the structural compartments of TDP43 by generating transgenic mice models overexpressing only C-terminal fragments or containing defective NLS human TDP43 (37, $72,113)$. Investigators observed only cognitive dysfunction and mild motor neurodegeneration in C-terminal fragments and defective NLS mice, respectively. This suggests that these domains may be involved in ALS (114), although they did not exactly mimic ALS.

Given that ALS-TDP43 cytoplasmic inclusions are typical in ALS, it is necessary to study these mutations, especially A315T, M337V, G348C, and A382T, reported to occur frequently (115-119). This review delves into the significance of these mutations in some transgenic lines (Table IV).

Some investigators generated human wild-type $T A R D B P^{A 315 T}$, and TARDBP ${ }^{G 34 C}$ transgenic mouse models by injecting DNA fragments, encompassing its human endogenous promoter subcloned from TARDBP-BAC into mice (116). In all three models studied, TDP43 overexpression was about three-fold compared to endogenous levels. All the models under investigation, contrary to those with higher expression that used exogenous promoters (112, $119,120)$, exhibited late disease onset at age 10 months. Of note, transgenic mice expressing TARDBP $348 C$ had more aggressive disease than mice with $T A R D B P^{A 315 T}$ and wild- 
type TARDBP (120). For example, aggregates containing peripherin proteins, pathognomonic of ALS, were identified in high amounts in the hippocampus and the cortex of $T A R D B P^{G 348 C}$ mice compared with TARDBP ${ }^{A 315 T}$ and wildtype $T A R D B P$ mice. Similarly, investigators found that microgliosis and astrogliosis were prominent in $T A R D B P^{G 348 C}$ than in TARDBP $P^{A 315 T}$ and wild-type TARDBP mice. Other researchers generated knock-in mouse models expressing heterozygous human TARDBP $P^{A 32 T}$ or $T A R D B P^{G 348 C}$ mutations, and found that disease onset was late in these mice (121). This indicated that the use of an endogenous promoter can be better to recapitulate signs and symptoms characteristic of ALS. In addition, the researchers reported that the levels of mutant mRNA and proteins in astrocytes were higher in TARDBP $A 382 T$ than $T A R D B P^{G 348 C}$ mice. In other TARDBP transgenic mouse models carrying the endogenous promoter, late disease onset was documented in mice with mutant $T A R D B P^{M 337 V}$ and $T A R D B P^{Q 331 K}$ expressing exogenous promoters $(118,122)$. Janssens et al. demonstrated hindlimb clasping at less than 1 month of age in mice with mutant TARDBP ${ }^{M 337 V}$ driven by a Thy-1.2 promoter (118), whereas Wang et al. described cortical neuronal loss driven by a prion promoter in transgenic mice at 12 months of age (122). According to some investigators, the level of $T D P 43^{M 337 V}$ in hemizygous TARDBP $P^{M 37 V}$ mice was not enough to reach the minimum level required to cause motor neuron death (in the spinal cord), which is a typical feature necessary for the onset of ALS-like phenotypes such as muscle weakness and paralysis (122). However, this hypothesis should be further investigated. Conversely, other researchers described motor deficits at 3 and 10 months of age in $T A R D B P^{Q 331 K}$ and TARDBP $P^{M 337 V}$ mice, respectively; these were under the control of mouse prion promoter (110). The mice in this model did not exhibit cytoplasmic TDP43 aggregations and on the contrary, TDP43 proteins were localized in the nucleus. Nevertheless, aberrant splicing events were observed in some RNA targets and enhanced in others. Thus, it can be presumed that mutations in TDP43 cause ALS through LOF and GOF in the absence of toxicity. In yet another study, investigators used the Cre recombinase system to reduce $T D P 43^{Q 331 K}$ expression in neurons and discovered that disease onset was delayed; however, this did not stop it from progressing (123).

Overall, it can be deduced from the findings above that overexpression of TDP43 at very high levels, especially in mice with $A 315 T$ mutation, can cause premature death, most likely due to gastrointestinal complications $(124,125)$. In addition, the use of either low protein expression or endogenous promoter correlates with late-onset motor dysfunction. Therefore, mice in these models develop signs that are reminiscent of TDP43related ALS. Regarding the mechanism underlying neuronal toxicity, the subject remains a controversial issue, and further studies are warranted in this domain.

\section{Conclusion}

Much has been achieved in the field of genetic research, especially in understanding the pathogenesis of neurodegenerative diseases such as ALS. It was not until recently that researchers understood why it was important to determine the underlying mechanism of LOF and GOF. Despite advances in our knowledge of the mechanisms underlying the development of ALS, the disease remains fatal. Researchers have only been able to develop mouse models that closely mimic ALS in humans; however, none of these models mimic the exact pathophysiology of the disease in humans, and current treatments can only relieve symptoms, not provide a cure. This review provides a deep insight into the best mouse models that have been generated to date. These models can serve as a basis for further research into developing better models that can potentially help in identifying an effective therapy against ALS.

\section{Acknowledgements}

The Author would like to thank Dr. Aida Mohammedeid (Ph.D. of neuroscience) for her help in editing some parts of this article.

\section{References}

1 Mitsumoto $\mathrm{H}$, Brooks BR and Silani V: Clinical trials in amyotrophic lateral sclerosis: Why so many negative trials and how can trials be improved? Lancet Neurol 13(11): 1127-1138, 2014.

2 Scarrott JM, Herranz-Martin S, Alrafiah AR, Shaw PJ and Azzouz M: Current developments in gene therapy for amyotrophic lateral sclerosis. Expert Opin Biol Ther 15(7): 935-947, 2015.

3 Deitch JS, Alexander GM, Bensinger A, Yang S, Jiang JT and Heiman-Patterson TD: Phenotype of transgenic mice carrying a very low copy number of the mutant human g93a superoxide dismutase-1 gene associated with amyotrophic lateral sclerosis. PLoS One 9(6): e99879, 2014.

4 Karch CM, Prudencio M, Winkler DD, Hart PJ and Borchelt DR: Role of mutant sod1 disulfide oxidation and aggregation in the pathogenesis of familial als. Proc Natl Acad Sci USA 106(19): 7774-7779, 2009.

5 Milanese M, Giribaldi F, Melone M, Bonifacino T, Musante I, Carminati E, Rossi PI, Vergani L, Voci A, Conti F, Puliti A and Bonanno G: Knocking down metabotropic glutamate receptor 1 improves survival and disease progression in the sod1(g93a) mouse model of amyotrophic lateral sclerosis. Neurobiol Dis 64: 48-59, 2014.

6 Tripolszki K, Csanyi B, Nagy D, Ratti A, Tiloca C, Silani V, Kereszty E, Torok N, Vecsei L, Engelhardt JI, Klivenyi P, Nagy $\mathrm{N}$ and Szell M: Genetic analysis of the sod1 and c9orf72 genes in hungarian patients with amyotrophic lateral sclerosis. Neurobiol Aging 53: 195 e191-195 e195, 2017.

7 Hooten KG, Beers DR, Zhao W and Appel SH: Protective and toxic neuroinflammation in amyotrophic lateral sclerosis. Neurotherapeutics 12(2): 364-375, 2015. 
8 Leblond CS, Kaneb HM, Dion PA and Rouleau GA: Dissection of genetic factors associated with amyotrophic lateral sclerosis. Exp Neurol 262 Pt B: 91-101, 2014.

9 Igaz LM, Kwong LK, Lee EB, Chen-Plotkin A, Swanson E, Unger T, Malunda J, Xu Y, Winton MJ, Trojanowski JQ and Lee VM: Dysregulation of the als-associated gene tdp-43 leads to neuronal death and degeneration in mice. J Clin Invest 121(2): 726-738, 2011.

10 Huang EJ, Zhang J, Geser F, Trojanowski JQ, Strober JB, Dickson DW, Brown RH, Jr., Shapiro BE and Lomen-Hoerth C: Extensive fus-immunoreactive pathology in juvenile amyotrophic lateral sclerosis with basophilic inclusions. Brain Pathol 20(6): 1069-1076, 2010.

11 Pitzer C, Kruger C, Plaas C, Kirsch F, Dittgen T, Muller R, Laage R, Kastner S, Suess S, Spoelgen R, Henriques A, Ehrenreich H, Schabitz WR, Bach A and Schneider A: Granulocyte-colony stimulating factor improves outcome in a mouse model of amyotrophic lateral sclerosis. Brain 131(Pt 12): 3335-3347, 2008.

12 DeJesus-Hernandez M, Mackenzie IR, Boeve BF, Boxer AL, Baker M, Rutherford NJ, Nicholson AM, Finch NA, Flynn H, Adamson J, Kouri N, Wojtas A, Sengdy P, Hsiung GY, Karydas A, Seeley WW, Josephs KA, Coppola G, Geschwind DH, Wszolek ZK, Feldman H, Knopman DS, Petersen RC, Miller BL, Dickson DW, Boylan KB, Graff-Radford NR and Rademakers R: Expanded ggggcc hexanucleotide repeat in noncoding region of c9orf72 causes chromosome 9p-linked ftd and als. Neuron 72(2): 245-256, 2011.

13 Renton AE, Majounie E, Waite A, Simon-Sanchez J, Rollinson S, Gibbs JR, Schymick JC, Laaksovirta H, van Swieten JC, Myllykangas L, Kalimo H, Paetau A, Abramzon Y, Remes AM, Kaganovich A, Scholz SW, Duckworth J, Ding J, Harmer DW, Hernandez DG, Johnson JO, Mok K, Ryten M, Trabzuni D, Guerreiro RJ, Orrell RW, Neal J, Murray A, Pearson J, Jansen IE, Sondervan D, Seelaar H, Blake D, Young K, Halliwell N, Callister JB, Toulson G, Richardson A, Gerhard A, Snowden J, Mann D, Neary D, Nalls MA, Peuralinna T, Jansson L, Isoviita VM, Kaivorinne AL, Holtta-Vuori M, Ikonen E, Sulkava R, Benatar M, Wuu J, Chio A, Restagno G, Borghero G, Sabatelli M, Consortium I, Heckerman D, Rogaeva E, Zinman L, Rothstein JD, Sendtner M, Drepper C, Eichler EE, Alkan C, Abdullaev Z, Pack SD, Dutra A, Pak E, Hardy J, Singleton A, Williams NM, Heutink P, Pickering-Brown S, Morris HR, Tienari PJ and Traynor BJ: A hexanucleotide repeat expansion in c9orf72 is the cause of chromosome 9p21-linked als-ftd. Neuron 72(2): 257-268, 2011.

14 Miller BL: The c9orf72 mutation brings more answers and more questions. Alzheimers Res Ther 5(1): 7, 2013.

15 Donnelly CJ, Grima JC and Sattler R: Aberrant rna homeostasis in amyotrophic lateral sclerosis: Potential for new therapeutic targets? Neurodegener Dis Manag 4(6): 417-437, 2014.

16 Belzil VV, Bauer PO, Prudencio M, Gendron TF, Stetler CT, Yan IK, Pregent L, Daughrity L, Baker MC, Rademakers R, Boylan K, Patel TC, Dickson DW and Petrucelli L: Reduced c9orf72 gene expression in c9ftd/als is caused by histone trimethylation, an epigenetic event detectable in blood. Acta Neuropathol 126(6): 895-905, 2013.

17 Ciura S, Lattante S, Le Ber I, Latouche M, Tostivint H, Brice A and Kabashi E: Loss of function of c9orf72 causes motor deficits in a zebrafish model of amyotrophic lateral sclerosis. Ann Neurol 74(2): 180-187, 2013.
18 Therrien M, Rouleau GA, Dion PA and Parker JA: Deletion of c9orf72 results in motor neuron degeneration and stress sensitivity in c. Elegans. PLoS One 8(12): e83450, 2013.

19 Liu EY, Russ J, Wu K, Neal D, Suh E, McNally AG, Irwin DJ, Van Deerlin VM and Lee EB: C9orf72 hypermethylation protects against repeat expansion-associated pathology in als/ftd. Acta Neuropathol 128(4): 525-541, 2014.

20 Mizielinska S and Isaacs AM: C9orf72 amyotrophic lateral sclerosis and frontotemporal dementia: Gain or loss of function? Curr Opin Neurol 27(5): 515-523, 2014.

21 Lagier-Tourenne C, Baughn M, Rigo F, Sun S, Liu P, Li HR, Jiang J, Watt AT, Chun S, Katz M, Qiu J, Sun Y, Ling SC, Zhu Q, Polymenidou M, Drenner K, Artates JW, McAlonis-Downes M, Markmiller S, Hutt KR, Pizzo DP, Cady J, Harms MB, Baloh RH, Vandenberg SR, Yeo GW, Fu XD, Bennett CF, Cleveland DW and Ravits J: Targeted degradation of sense and antisense c9orf72 rna foci as therapy for als and frontotemporal degeneration. Proc Natl Acad Sci USA 110(47): E4530-4539, 2013.

22 Harms MB, Cady J, Zaidman C, Cooper P, Bali T, Allred P, Cruchaga C, Baughn M, Libby RT, Pestronk A, Goate A, Ravits $\mathrm{J}$ and Baloh RH: Lack of c9orf72 coding mutations supports a gain of function for repeat expansions in amyotrophic lateral sclerosis. Neurobiol Aging 34(9): 2234 e2213-2239, 2013.

23 Yanovsky-Dagan S, Mor-Shaked H and Eiges R: Modeling diseases of noncoding unstable repeat expansions using mutant pluripotent stem cells. World J Stem Cells 7(5): 823-838, 2015.

24 O'Rourke JG, Bogdanik L, Muhammad A, Gendron TF, Kim KJ, Austin A, Cady J, Liu EY, Zarrow J, Grant S, Ho R, Bell S, Carmona S, Simpkinson M, Lall D, Wu K, Daughrity L, Dickson DW, Harms MB, Petrucelli L, Lee EB, Lutz CM and Baloh RH: C9orf72 bac transgenic mice display typical pathologic features of als/ftd. Neuron 88(5): 892-901, 2015.

25 Peters OM, Cabrera GT, Tran H, Gendron TF, McKeon JE, Metterville J, Weiss A, Wightman N, Salameh J, Kim J, Sun H, Boylan KB, Dickson D, Kennedy Z, Lin Z, Zhang YJ, Daughrity L, Jung C, Gao FB, Sapp PC, Horvitz HR, Bosco DA, Brown SP, de Jong P, Petrucelli L, Mueller C and Brown RH, Jr.: Human c9orf72 hexanucleotide expansion reproduces rna foci and dipeptide repeat proteins but not neurodegeneration in bac transgenic mice. Neuron 88(5): 902-909, 2015.

26 Zhang YJ, Gendron TF, Grima JC, Sasaguri H, Jansen-West K, Xu YF, Katzman RB, Gass J, Murray ME, Shinohara M, Lin WL, Garrett A, Stankowski JN, Daughrity L, Tong J, Perkerson EA, Yue M, Chew J, Castanedes-Casey M, Kurti A, Wang ZS, Liesinger AM, Baker JD, Jiang J, Lagier-Tourenne C, Edbauer D, Cleveland DW, Rademakers R, Boylan KB, Bu G, Link CD, Dickey CA, Rothstein JD, Dickson DW, Fryer JD and Petrucelli L: C9orf72 poly(ga) aggregates sequester and impair hr23 and nucleocytoplasmic transport proteins. Nat Neurosci 19(5): 668677, 2016.

27 Chew J, Gendron TF, Prudencio M, Sasaguri H, Zhang YJ, Castanedes-Casey M, Lee CW, Jansen-West K, Kurti A, Murray ME, Bieniek KF, Bauer PO, Whitelaw EC, Rousseau L, Stankowski JN, Stetler C, Daughrity LM, Perkerson EA, Desaro P, Johnston A, Overstreet K, Edbauer D, Rademakers R, Boylan KB, Dickson DW, Fryer JD and Petrucelli L: Neurodegeneration. C9orf72 repeat expansions in mice cause tdp-43 pathology, neuronal loss, and behavioral deficits. Science 348(6239): 1151-1154, 2015. 
28 Jiang J, Zhu Q, Gendron TF, Saberi S, McAlonis-Downes M, Seelman A, Stauffer JE, Jafar-Nejad P, Drenner K, Schulte D, Chun S, Sun S, Ling SC, Myers B, Engelhardt J, Katz M, Baughn M, Platoshyn O, Marsala M, Watt A, Heyser CJ, Ard MC, De Muynck L, Daughrity LM, Swing DA, Tessarollo L, Jung CJ, Delpoux A, Utzschneider DT, Hedrick SM, de Jong PJ, Edbauer D, Van Damme P, Petrucelli L, Shaw CE, Bennett CF, Da Cruz S, Ravits J, Rigo F, Cleveland DW and LagierTourenne C: Gain of toxicity from als/ftd-linked repeat expansions in c9orf72 is alleviated by antisense oligonucleotides targeting ggggcc-containing rnas. Neuron 90(3): 535-550, 2016.

29 Liu Y, Pattamatta A, Zu T, Reid T, Bardhi O, Borchelt DR, Yachnis AT and Ranum LP: C9orf72 bac mouse model with motor deficits and neurodegenerative features of als/ftd. Neuron 90(3): 521-534, 2016.

30 Gurney ME, Pu H, Chiu AY, Dal Canto MC, Polchow CY, Alexander DD, Caliendo J, Hentati A, Kwon YW, Deng HX and et al:: Motor neuron degeneration in mice that express a human cu,zn superoxide dismutase mutation. Science 264(5166): 1772-1775, 1994

31 Jaarsma D, Haasdijk ED, Grashorn JA, Hawkins R, van Duijn W, Verspaget HW, London J and Holstege JC: Human cu/zn superoxide dismutase $(\operatorname{sod} 1)$ overexpression in mice causes mitochondrial vacuolization, axonal degeneration, and premature motoneuron death and accelerates motoneuron disease in mice expressing a familial amyotrophic lateral sclerosis mutant sod1. Neurobiol Dis 7(6 Pt B): 623-643, 2000.

32 Jonsson PA, Graffmo KS, Brannstrom T, Nilsson P, Andersen PM and Marklund SL: Motor neuron disease in mice expressing the wild type-like d90a mutant superoxide dismutase-1. J Neuropathol Exp Neurol 65(12): 1126-1136, 2006.

33 Quarta E, Bravi R, Scambi I, Mariotti R and Minciacchi D: Increased anxiety-like behavior and selective learning impairments are concomitant to loss of hippocampal interneurons in the presymptomatic sod $1(\mathrm{~g} 93 \mathrm{a})$ als mouse model. J Comp Neurol 523(11): 1622-1638, 2015.

34 Dal Canto MC and Gurney ME: A low expressor line of transgenic mice carrying a mutant human cu,zn superoxide dismutase (sod1) gene develops pathological changes that most closely resemble those in human amyotrophic lateral sclerosis. Acta Neuropathol 93(6): 537-550, 1997.

35 Graffmo KS, Forsberg K, Bergh J, Birve A, Zetterstrom P, Andersen PM, Marklund SL and Brannstrom T: Expression of wild-type human superoxide dismutase-1 in mice causes amyotrophic lateral sclerosis. Hum Mol Genet 22(1): 51-60, 2013.

36 Tafuri F, Ronchi D, Magri F, Comi GP and Corti S: Sod1 misplacing and mitochondrial dysfunction in amyotrophic lateral sclerosis pathogenesis. Front Cell Neurosci 9: 336, 2015.

37 Liu YC, Chiang PM and Tsai KJ: Disease animal models of tdp-43 proteinopathy and their pre-clinical applications. Int J Mol Sci 14(10): 20079-20111, 2013.

38 Vande Velde C, Miller TM, Cashman NR and Cleveland DW: Selective association of misfolded als-linked mutant sod 1 with the cytoplasmic face of mitochondria. Proc Natl Acad Sci U S A 105(10): 4022-4027, 2008

39 Liu J, Lillo C, Jonsson PA, Vande Velde C, Ward CM, Miller TM, Subramaniam JR, Rothstein JD, Marklund S, Andersen PM, Brannstrom T, Gredal O, Wong PC, Williams DS and Cleveland DW: Toxicity of familial als-linked sod1 mutants from selective recruitment to spinal mitochondria. Neuron 43(1): 5-17, 2004

40 Kato S, Takikawa M, Nakashima K, Hirano A, Cleveland DW, Kusaka H, Shibata N, Kato M, Nakano I and Ohama E: New consensus research on neuropathological aspects of familial amyotrophic lateral sclerosis with superoxide dismutase 1 (sod1) gene mutations: Inclusions containing sod1 in neurons and astrocytes. Amyotroph Lateral Scler Other Motor Neuron Disord 1(3): 163-184, 2000.

41 Jaiswal MK, Zech WD, Goos M, Leutbecher C, Ferri A, Zippelius A, Carri MT, Nau R and Keller BU: Impairment of mitochondrial calcium handling in a mtsod 1 cell culture model of motoneuron disease. BMC Neurosci 10: 64, 2009.

42 Liu XA, Rizzo V and Puthanveettil SV: Pathologies of axonal transport in neurodegenerative diseases. Transl Neurosci 3(4): 355-372, 2012.

43 Morfini GA, Burns M, Binder LI, Kanaan NM, LaPointe N, Bosco DA, Brown RH, Jr., Brown H, Tiwari A, Hayward L, Edgar J, Nave KA, Garberrn J, Atagi Y, Song Y, Pigino G and Brady ST: Axonal transport defects in neurodegenerative diseases. J Neurosci 29(41): 12776-12786, 2009.

44 Zhang B, Tu P, Abtahian F, Trojanowski JQ and Lee VM: Neurofilaments and orthograde transport are reduced in ventral root axons of transgenic mice that express human sod1 with a g93a mutation. J Cell Biol 139(5): 1307-1315, 1997.

45 Collard JF, Cote F and Julien JP: Defective axonal transport in a transgenic mouse model of amyotrophic lateral sclerosis. Nature 375(6526): 61-64, 1995.

46 Munch C, Sedlmeier R, Meyer T, Homberg V, Sperfeld AD, Kurt A, Prudlo J, Peraus G, Hanemann CO, Stumm G and Ludolph AC: Point mutations of the p150 subunit of dynactin (dctn1) gene in als. Neurology 63(4): 724-726, 2004.

47 Puls I, Jonnakuty C, LaMonte BH, Holzbaur EL, Tokito M, Mann E, Floeter MK, Bidus K, Drayna D, Oh SJ, Brown RH, Jr., Ludlow CL and Fischbeck KH: Mutant dynactin in motor neuron disease. Nat Genet 33(4): 455-456, 2003.

48 Soo KY, Farg M and Atkin JD: Molecular motor proteins and amyotrophic lateral sclerosis. Int J Mol Sci 12(12): 9057-9082, 2011.

49 Urushitani M, Sik A, Sakurai T, Nukina N, Takahashi R and Julien JP: Chromogranin-mediated secretion of mutant superoxide dismutase proteins linked to amyotrophic lateral sclerosis. Nat Neurosci 9(1): 108-118, 2006.

50 Zhao W, Beers DR, Henkel JS, Zhang W, Urushitani M, Julien JP and Appel SH: Extracellular mutant sod1 induces microglialmediated motoneuron injury. Glia 58(2): 231-243, 2010.

51 Boillee S, Yamanaka K, Lobsiger CS, Copeland NG, Jenkins NA, Kassiotis G, Kollias G and Cleveland DW: Onset and progression in inherited als determined by motor neurons and microglia. Science 312(5778): 1389-1392, 2006.

52 Yamanaka K, Chun SJ, Boillee S, Fujimori-Tonou N, Yamashita H, Gutmann DH, Takahashi R, Misawa H and Cleveland DW: Astrocytes as determinants of disease progression in inherited amyotrophic lateral sclerosis. Nat Neurosci 11(3): 251-253, 2008.

53 Lepore AC, Rauck B, Dejea C, Pardo AC, Rao MS, Rothstein JD and Maragakis NJ: Focal transplantation-based astrocyte replacement is neuroprotective in a model of motor neuron disease. Nat Neurosci 11(11): 1294-1301, 2008. 
54 Ilieva $\mathrm{H}$, Polymenidou $\mathrm{M}$ and Cleveland DW: Non-cell autonomous toxicity in neurodegenerative disorders: Als and beyond. J Cell Biol 187(6): 761-772, 2009.

55 Saccon RA, Bunton-Stasyshyn RK, Fisher EM and Fratta P: Is sod1 loss of function involved in amyotrophic lateral sclerosis? Brain 136(Pt 8): 2342-2358, 2013.

56 Deepa SS, Bhaskaran S, Espinoza S, Brooks SV, McArdle A, Jackson MJ, Van Remmen $\mathrm{H}$ and Richardson A: A new mouse model of frailty: The cu/zn superoxide dismutase knockout mouse. Geroscience 39(2): 187-198, 2017.

57 Reaume AG, Elliott JL, Hoffman EK, Kowall NW, Ferrante RJ, Siwek DF, Wilcox HM, Flood DG, Beal MF, Brown RH Jr., Scott RW and Snider WD: Motor neurons in cu/zn superoxide dismutase-deficient mice develop normally but exhibit enhanced cell death after axonal injury. Nat Genet 13(1): 4347, 1996.

58 Sentman ML, Granstrom M, Jakobson H, Reaume A, Basu S and Marklund SL: Phenotypes of mice lacking extracellular superoxide dismutase and copper- and zinc-containing superoxide dismutase. J Biol Chem 281(11): 6904-6909, 2006.

59 Epstein CJ, Avraham KB, Lovett M, Smith S, Elroy-Stein O, Rotman G, Bry C and Groner Y: Transgenic mice with increased cu/zn-superoxide dismutase activity: Animal model of dosage effects in down syndrome. Proc Natl Acad Sci USA 84(22): 8044-8048, 1987.

60 Cudkowicz ME, McKenna-Yasek D, Sapp PE, Chin W, Geller B, Hayden DL, Schoenfeld DA, Hosler BA, Horvitz HR and Brown RH: Epidemiology of mutations in superoxide dismutase in amyotrophic lateral sclerosis. Ann Neurol 41(2): 210-221, 1997.

61 McCombe PA and Henderson RD: Effects of gender in amyotrophic lateral sclerosis. Gend Med 7(6): 557-570, 2010.

62 Dal Canto MC and Gurney ME: Neuropathological changes in two lines of mice carrying a transgene for mutant human cu,zn sod, and in mice overexpressing wild type human sod: A model of familial amyotrophic lateral sclerosis (fals). Brain Res 676(1): 25-40, 1995.

63 Gowing G, Philips T, Van Wijmeersch B, Audet JN, Dewil M, Van Den Bosch L, Billiau AD, Robberecht W and Julien JP: Ablation of proliferating microglia does not affect motor neuron degeneration in amyotrophic lateral sclerosis caused by mutant superoxide dismutase. J Neurosci 28(41): 10234-10244, 2008.

64 Blair IP, Williams KL, Warraich ST, Durnall JC, Thoeng AD, Manavis J, Blumbergs PC, Vucic S, Kiernan MC and Nicholson GA: Fus mutations in amyotrophic lateral sclerosis: Clinical, pathological, neurophysiological and genetic analysis. J Neurol Neurosurg Psychiatry 81(6): 639-645, 2010.

65 Alami NH, Smith RB, Carrasco MA, Williams LA, Winborn CS, Han SSW, Kiskinis E, Winborn B, Freibaum BD Kanagaraj A, Clare AJ, Badders NM, Bilican B, Chaum E, Chandran S, Shaw CE, Eggan KC, Maniatis T and Taylor JP: Axonal transport of tdp-43 mrna granules is impaired by alscausing mutations. Neuron 81(3): 536-543, 2014.

66 Cannon A, Yang B, Knight J, Farnham IM, Zhang Y, Wuertzer CA, D'Alton S, Lin WL, Castanedes-Casey M, Rousseau L, Scott B, Jurasic M, Howard J, Yu X, Bailey R, Sarkisian MR, Dickson DW, Petrucelli L and Lewis J: Neuronal sensitivity to tdp-43 overexpression is dependent on timing of induction. Acta Neuropathol 123(6): 807-823, 2012.
67 Van Langenhove T, van der Zee J, Sleegers K, Engelborghs S, Vandenberghe $\mathrm{R}$, Gijselinck $\mathrm{I}$, Van den Broeck $\mathrm{M}$, Mattheijssens M, Peeters K, De Deyn PP, Cruts M and Van Broeckhoven C: Genetic contribution of fus to frontotemporal lobar degeneration. Neurology 74(5): 366-371, 2010.

68 Rademakers R, Stewart H, Dejesus-Hernandez M, Krieger C, Graff-Radford N, Fabros M, Briemberg H, Cashman N, Eisen $A$ and Mackenzie IR: Fus gene mutations in familial and sporadic amyotrophic lateral sclerosis. Muscle Nerve 42(2): 170-176, 2010.

69 Waibel S, Neumann M, Rosenbohm A, Birve A, Volk AE, Weishaupt JH, Meyer T, Muller U, Andersen PM and Ludolph AC: Truncating mutations in fus/tls give rise to a more aggressive als-phenotype than missense mutations: A clinicogenetic study in germany. Eur J Neurol 20(3): 540-546, 2013.

70 Deng $\mathrm{H}$, Gao K and Jankovic J: The role of fus gene variants in neurodegenerative diseases. Nat Rev Neurol 10(6): 337-348, 2014

71 Nolan M, Talbot K and Ansorge O: Pathogenesis of fusassociated als and ftd: Insights from rodent models. Acta Neuropathol Commun 4(1): 99, 2016.

72 Corcia P, Danel V, Lacour A, Beltran S, Andres C, Couratier P, Blasco H and Vourc'h P: A novel mutation of the c-terminal amino acid of fus (y526c) strengthens fus gene as the most frequent genetic factor in aggressive juvenile als. Amyotroph Lateral Scler Frontotemporal Degener 18(3-4): 298-301, 2017.

73 Efimova AD, Ovchinnikov RK, Roman AY, Maltsev AV, Grigoriev VV, Kovrazhkina EA and Skvortsova VI: [the fus protein: Physiological functions and a role in amyotrophic lateral sclerosis]. Mol Biol (Mosk) 51(3): 387-399, 2017.

74 Brelstaff J, Lashley T, Holton JL, Lees AJ, Rossor MN, Bandopadhyay R and Revesz T: Transportin1: A marker of ftldfus. Acta Neuropathol 122(5): 591-600, 2011.

75 Sharma A, Lyashchenko AK, Lu L, Nasrabady SE, Elmaleh M, Mendelsohn M, Nemes A, Tapia JC, Mentis GZ and Shneider NA: Als-associated mutant fus induces selective motor neuron degeneration through toxic gain of function. Nat Commun 7: 10465, 2016.

76 Dobbin MM, Madabhushi R, Pan L, Chen Y, Kim D, Gao J, Ahanonu B, Pao PC, Qiu Y, Zhao Y and Tsai LH: Sirt1 collaborates with atm and hdac1 to maintain genomic stability in neurons. Nat Neurosci 16(8): 1008-1015, 2013.

77 Wang WY, Pan L, Su SC, Quinn EJ, Sasaki M, Jimenez JC, Mackenzie IR, Huang EJ and Tsai LH: Interaction of fus and hdac1 regulates DNA damage response and repair in neurons. Nat Neurosci 16(10): 1383-1391, 2013.

78 Baumer D, Hilton D, Paine SM, Turner MR, Lowe J, Talbot K and Ansorge O: Juvenile als with basophilic inclusions is a fus proteinopathy with fus mutations. Neurology 75(7): 611-618, 2010.

79 Verbeeck C, Deng Q, Dejesus-Hernandez M, Taylor G, Ceballos-Diaz C, Kocerha J, Golde T, Das P, Rademakers R, Dickson DW and Kukar T: Expression of fused in sarcoma mutations in mice recapitulates the neuropathology of fus proteinopathies and provides insight into disease pathogenesis. Mol Neurodegener 7: 53, 2012.

80 Huang C, Tong J, Bi F, Wu Q, Huang B, Zhou H and Xia XG: Entorhinal cortical neurons are the primary targets of fus mislocalization and ubiquitin aggregation in fus transgenic rats. Hum Mol Genet 21(21): 4602-4614, 2012. 
81 Armstrong GA and Drapeau P: Loss and gain of fus function impair neuromuscular synaptic transmission in a genetic model of als. Hum Mol Genet 22(21): 4282-4292, 2013.

82 Qiu H, Lee S, Shang Y, Wang WY, Au KF, Kamiya S, Barmada SJ, Finkbeiner S, Lui H, Carlton CE, Tang AA, Oldham MC, Wang H, Shorter J, Filiano AJ, Roberson ED, Tourtellotte WG, Chen B, Tsai LH and Huang EJ: Als-associated mutation fusr521c causes DNA damage and rna splicing defects. J Clin Invest 124(3): 981-999, 2014.

83 Dichmann DS and Harland RM: Fus/tls orchestrates splicing of developmental regulators during gastrulation. Genes Dev 26(12): 1351-1363, 2012.

84 Shang Y and Huang EJ: Mechanisms of fus mutations in familial amyotrophic lateral sclerosis. Brain Res 1647: 65-78, 2016.

85 Mitchell JC, McGoldrick P, Vance C, Hortobagyi T, Sreedharan J, Rogelj B, Tudor EL, Smith BN, Klasen C, Miller CC, Cooper JD, Greensmith L and Shaw CE: Overexpression of human wild-type fus causes progressive motor neuron degeneration in an age- and dose-dependent fashion. Acta Neuropathol 125(2): 273-288, 2013.

86 Kino Y, Washizu C, Kurosawa M, Yamada M, Miyazaki H, Akagi T, Hashikawa T, Doi H, Takumi T, Hicks GG, Hattori N, Shimogori T and Nukina N: Fus/tls deficiency causes behavioral and pathological abnormalities distinct from amyotrophic lateral sclerosis. Acta Neuropathol Commun 3: 24, 2015.

87 Sun S, Ling SC, Qiu J, Albuquerque CP, Zhou Y, Tokunaga S, Li H, Qiu H, Bui A, Yeo GW, Huang EJ, Eggan K, Zhou H, Fu XD, Lagier-Tourenne $\mathrm{C}$ and Cleveland DW: Als-causative mutations in fus/tls confer gain and loss of function by altered association with smn and u1-snrnp. Nat Commun 6: 6171, 2015.

88 Deng HX, Zhai H, Bigio EH, Yan J, Fecto F, Ajroud K, Mishra M, Ajroud-Driss S, Heller S, Sufit R, Siddique N, Mugnaini E and Siddique T: Fus-immunoreactive inclusions are a common feature in sporadic and non-sod 1 familial amyotrophic lateral sclerosis. Ann Neurol 67(6): 739-748, 2010.

89 Sephton CF, Tang AA, Kulkarni A, West J, Brooks M, Stubblefield JJ, Liu Y, Zhang MQ, Green CB, Huber KM, Huang EJ, Herz J and Yu G: Activity-dependent fus dysregulation disrupts synaptic homeostasis. Proc Natl Acad Sci USA 111(44): E4769-4778, 2014.

90 Neumann M, Sampathu DM, Kwong LK, Truax AC, Micsenyi MC, Chou TT, Bruce J, Schuck T, Grossman M, Clark CM, McCluskey LF, Miller BL, Masliah E, Mackenzie IR, Feldman H, Feiden W, Kretzschmar HA, Trojanowski JQ and Lee VM: Ubiquitinated tdp-43 in frontotemporal lobar degeneration and amyotrophic lateral sclerosis. Science 314(5796): 130-133, 2006.

91 Yokoseki A, Shiga A, Tan CF, Tagawa A, Kaneko H, Koyama A, Eguchi H, Tsujino A, Ikeuchi T, Kakita A, Okamoto K, Nishizawa M, Takahashi $\mathrm{H}$ and Onodera O: Tdp-43 mutation in familial amyotrophic lateral sclerosis. Ann Neurol 63(4): 538-542, 2008

92 Sreedharan J, Blair IP, Tripathi VB, Hu X, Vance C, Rogelj B, Ackerley S, Durnall JC, Williams KL, Buratti E, Baralle F, de Belleroche J, Mitchell JD, Leigh PN, Al-Chalabi A, Miller CC, Nicholson $G$ and Shaw CE: Tdp-43 mutations in familial and sporadic amyotrophic lateral sclerosis. Science 319(5870): 1668-1672, 2008.

93 Abel O, Shatunov A, Jones AR, Andersen PM, Powell JF and Al-Chalabi A: Development of a smartphone app for a genetics website: The amyotrophic lateral sclerosis online genetics database (alsod). JMIR Mhealth Uhealth 1(2): e18, 2013.
94 Lee EB, Lee VM and Trojanowski JQ: Gains or losses: Molecular mechanisms of tdp43-mediated neurodegeneration. Nat Rev Neurosci 13(1): 38-50, 2011.

95 Scotter EL, Chen HJ and Shaw CE: Tdp-43 proteinopathy and als: Insights into disease mechanisms and therapeutic targets. Neurotherapeutics 12(2): 352-363, 2015.

96 Iguchi Y, Katsuno M, Takagi S, Ishigaki S, Niwa J, Hasegawa M, Tanaka F and Sobue G: Oxidative stress induced by glutathione depletion reproduces pathological modifications of tdp-43 linked to tdp-43 proteinopathies. Neurobiol Dis $45(3)$ : 862-870, 2012.

97 Parker SJ, Meyerowitz J, James JL, Liddell JR, Crouch PJ, Kanninen KM and White AR: Endogenous tdp-43 localized to stress granules can subsequently form protein aggregates. Neurochem Int 60(4): 415-424, 2012.

98 Cohen TJ, Lee VM and Trojanowski JQ: Tdp-43 functions and pathogenic mechanisms implicated in tdp-43 proteinopathies. Trends Mol Med 17(11): 659-667, 2011.

99 Tak H, Eun JW, Kim J, Park SJ, Kim C, Ji E, Lee H, Kang H, Cho DH, Lee K, Kim W, Nam SW and Lee EK: T-cellrestricted intracellular antigen 1 facilitates mitochondrial fragmentation by enhancing the expression of mitochondrial fission factor. Cell Death Differ 24(1): 49-58, 2017.

100 Shi P, Gal J, Kwinter DM, Liu X and Zhu H: Mitochondrial dysfunction in amyotrophic lateral sclerosis. Biochim Biophys Acta 1802(1): 45-51, 2010.

$101 \mathrm{Xu}$ YF, Zhang YJ, Lin WL, Cao X, Stetler C, Dickson DW, Lewis J and Petrucelli L: Expression of mutant tdp-43 induces neuronal dysfunction in transgenic mice. Mol Neurodegener 6: 73, 2011.

102 Fiesel FC, Schurr C, Weber SS and Kahle PJ: Tdp-43 knockdown impairs neurite outgrowth dependent on its target histone deacetylase 6. Mol Neurodegener 6: 64, 2011.

103 Sephton CF, Cenik B, Cenik BK, Herz J and Yu G: Tdp-43 in central nervous system development and function: Clues to tdp43-associated neurodegeneration. Biol Chem 393(7): 589-594, 2012.

104 Kawamata H, Peixoto P, Konrad C, Palomo G, Bredvik K, Gerges M, Valsecchi F, Petrucelli L, Ravits JM, Starkov A and Manfredi G: Mutant tdp-43 does not impair mitochondrial bioenergetics in vitro and in vivo. Mol Neurodegener 12(1): 37, 2017.

105 Wegorzewska I and Baloh RH: Tdp-43-based animal models of neurodegeneration: New insights into als pathology and pathophysiology. Neurodegener Dis 8(4): 262-274, 2011.

106 Kraemer BC, Schuck T, Wheeler JM, Robinson LC, Trojanowski JQ, Lee VM and Schellenberg GD: Loss of murine tdp-43 disrupts motor function and plays an essential role in embryogenesis. Acta Neuropathol 119(4): 409-419, 2010.

107 Wu LS, Cheng WC, Hou SC, Yan YT, Jiang ST and Shen CK: Tdp-43, a neuro-pathosignature factor, is essential for early mouse embryogenesis. Genesis 48(1): 56-62, 2010.

108 Alfieri JA, Silva PR and Igaz LM: Early cognitive/social deficits and late motor phenotype in conditional wild-type tdp43 transgenic mice. Front Aging Neurosci 8: 310, 2016.

109 Prpar Miheve S, Baralle M, Buratti E and Rogelj B: Tdp-43 aggregation mirrors tdp-43 knockdown, affecting the expression levels of a common set of proteins. Sci Rep 6: 33996, 2016. 
110 Arnold ES, Ling SC, Huelga SC, Lagier-Tourenne C, Polymenidou M, Ditsworth D, Kordasiewicz HB, McAlonisDownes M, Platoshyn O, Parone PA, Da Cruz S, Clutario KM, Swing D, Tessarollo L, Marsala M, Shaw CE, Yeo GW and Cleveland DW: Als-linked tdp-43 mutations produce aberrant rna splicing and adult-onset motor neuron disease without aggregation or loss of nuclear tdp-43. Proc Natl Acad Sci USA 110(8): E736-745, 2013.

111 Tsai KJ, Yang CH, Fang YH, Cho KH, Chien WL, Wang WT, Wu TW, Lin CP, Fu WM and Shen CK: Elevated expression of tdp-43 in the forebrain of mice is sufficient to cause neurological and pathological phenotypes mimicking ftld-u. J Exp Med 207(8): 1661-1673, 2010.

112 Stallings NR, Puttaparthi K, Luther CM, Burns DK and Elliott JL: Progressive motor weakness in transgenic mice expressing human tdp-43. Neurobiol Dis 40(2): 404-414, 2010.

113 Caccamo A, Majumder S and Oddo S: Cognitive decline typical of frontotemporal lobar degeneration in transgenic mice expressing the 25-kda c-terminal fragment of tdp-43. Am J Pathol 180(1): 293-302, 2012.

114 Fiesel FC and Kahle PJ: Tdp-43 and fus/tls: Cellular functions and implications for neurodegeneration. FEBS J 278(19): 35503568, 2011.

115 Corcia P, Valdmanis P, Millecamps S, Lionnet C, Blasco H, Mouzat K, Daoud H, Belzil V, Morales R, Pageot N, DanelBrunaud V, Vandenberghe N, Pradat PF, Couratier P, Salachas F, Lumbroso S, Rouleau GA, Meininger V and Camu W: Phenotype and genotype analysis in amyotrophic lateral sclerosis with tardbp gene mutations. Neurology 78(19): 15191526, 2012.

116 Swarup V, Phaneuf D, Bareil C, Robertson J, Rouleau GA, Kriz $\mathrm{J}$ and Julien JP: Pathological hallmarks of amyotrophic lateral sclerosis/frontotemporal lobar degeneration in transgenic mice produced with tdp-43 genomic fragments. Brain 134(Pt 9): 2610-2626, 2011.

117 Wils H, Kleinberger G, Janssens J, Pereson S, Joris G, Cuijt I, Smits V, Ceuterick-de Groote C, Van Broeckhoven C and Kumar-Singh S: Tdp-43 transgenic mice develop spastic paralysis and neuronal inclusions characteristic of als and frontotemporal lobar degeneration. Proc Natl Acad Sci USA 107(8): 3858-3863, 2010.

118 Janssens J, Wils H, Kleinberger G, Joris G, Cuijt I, Ceuterickde Groote C, Van Broeckhoven $\mathrm{C}$ and Kumar-Singh S: Overexpression of als-associated p.M337v human tdp-43 in mice worsens disease features compared to wild-type human tdp-43 mice. Mol Neurobiol 48(1): 22-35, 2013.
119 Ke YD, van Hummel A, Stevens CH, Gladbach A, Ippati S, Bi M, Lee WS, Kruger S, van der Hoven J, Volkerling A, Bongers A, Halliday G, Haass NK, Kiernan M, Delerue F and Ittner LM: Short-term suppression of a315t mutant human tdp-43 expression improves functional deficits in a novel inducible transgenic mouse model of ftld-tdp and als. Acta Neuropathol 130(5): 661-678, 2015.

120 Wegorzewska I, Bell S, Cairns NJ, Miller TM and Baloh RH: Tdp-43 mutant transgenic mice develop features of als and frontotemporal lobar degeneration. Proc Natl Acad Sci USA 106(44): 18809-18814, 2009.

121 Hasegawa M, Hara-Miyauchi C, Ohta H, Sakimura K, Okano $\mathrm{H}$ and Okano $\mathrm{HJ}$ : Analysis of rna metabolism in peripheral wbcs of tdp-43 ki mice identifies novel biomarkers of als. Neurosci Res 106: 12-22, 2016.

122 Wang W, Arakawa H, Wang L, Okolo O, Siedlak SL, Jiang Y, Gao J, Xie F, Petersen RB and Wang X: Motor-coordinative and cognitive dysfunction caused by mutant tdp-43 could be reversed by inhibiting its mitochondrial localization. Mol Ther 25(1): 127-139, 2017.

123 Ditsworth D, Maldonado M, McAlonis-Downes M, Sun S, Seelman A, Drenner K, Arnold E, Ling SC, Pizzo D, Ravits J, Cleveland DW and Da Cruz S: Mutant tdp-43 within motor neurons drives disease onset but not progression in amyotrophic lateral sclerosis. Acta Neuropathol 133(6): 907-922, 2017.

124 Esmaeili MA, Panahi M, Yadav S, Hennings L and Kiaei M: Premature death of tdp-43 (a315t) transgenic mice due to gastrointestinal complications prior to development of full neurological symptoms of amyotrophic lateral sclerosis. Int $\mathbf{J}$ Exp Pathol 94(1): 56-64, 2013.

125 Guo Y, Wang Q, Zhang K, An T, Shi P, Li Z, Duan W and Li $\mathrm{C}$ : Ho-1 induction in motor cortex and intestinal dysfunction in tdp-43 a315t transgenic mice. Brain Res 1460: 88-95, 2012. 